\title{
MENINGKATKAN KEMAMPUAN BERPIKIR KRITIS DAN PENALARAN MATEMATIS SISWA MELALUI MODEL BRAIN BASED LEARNING
}

\author{
Dede Salim Nahdi ${ }^{1}$ \\ an_nahdi@yahoo.co.id \\ Universitas Majalengka
}

\begin{abstract}
ABSTRAK
Penelitian ini dilatarbelakangi dengan keprihatinan peneliti terhadap rendahnya kemampuan berpikir kritis dan penalaran matematis siswa di Sekolah Dasar. Hal ini dapat dilihat dari beberapa studi yang telah dilakukan, baik oleh lembaga internasional maupun studi yang dilakukan oleh individu. Peneliti memberikan solusi model Brain-Based Learning (BBL), suatu model pembelajaran yang mengoptimalkan kerja otak serta diperkirakan dapat meningkatkan kemampuan berpikir kritis dan dan penalaran matematis siswa.

Penelitian ini berbentuk studi kuasi eksperimen dengan desain penelitian berbentuk desain kelompok kontrol non ekuivalen. Peneliti memilih kuasi eksperimen karena pemilihan sampel tidak secara random tetapi menerima keadaan sampel seadanya atau disebut purposive sampling. Populasi dalam penelitian ini adalah siswa Sekolah Dasar Kabupaten Majalengka tahun pelajaran 2013/2014 dengan sampel penelitian siswa kelas V SD Negeri Cijati. Sampel yang diambil sebanyak dua kelas, dari dua kelas tersebut salah satunya digunakan sebagai kelas eksperimen yang memperoleh pembelajaran BBL, sedangkan kelas lainnya sebagai kelas kontrol yang menggunakan pembelajaran konvensional.

Kedua kelompok diberikan pretes dan postes kemampuan berpikir kritis dan penalaran matematis. Data $N$-gain yang dianalisis secara kuantitatif untuk melihat perbedaan kemampuan berpikir kritis dan penalaran matematis pada dua kelas dengan menggunakan uji perbedaan dua rata-rata parametrik uji-t. Hasil penelitian menunjukkan bahwa peningkatan kemampuan berpikir kritis dan penalaran matematis yang memperoleh pembelajaran dengan menggunakan BBL lebih baik daripada siswa yang menggunakan pembelajaran konvensional.
\end{abstract}

Kata kunci : Brain-Based Learning (BBL), kemampuan berpikir kritis matematis, kemampuan penalaran matematis.

Penulis adalah Dosen Tetap pada Prodi PGSD Fakultas Pendidikan Dasar dan Menengah Universitas Majalengka 


\section{Pendahuluan}

Pelaksanaan program wajib belajar 9 tahun dapat dipandang sebagai salah satu bentuk peningkatan kualitas sumber daya manusia di Indonesia, termasuk kualitas berpikirnya. Salah satu fungsi pendidikan adalah menyiapkan generasi mendatang yang lebih baik daripada generasi saat ini. Jika kehidupan yang akan datang sarat dengan problematika dan tantangan yang semakin kompleks, maka pendidikan harus dapat menyiapkan generasi yang mampu menjawab tantangan dan problematika yang dihadapinya, yakni menyiapkan generasi yang berkepribadian, terampil, kritis, dan kreatif.

Guru sekolah dasar perlu membekali kemampuan berpikir kritis siswanya. Hal ini dikarenakan seorang siswa SD yang hanya mempelajari materi saja tanpa dibekali kemampuan ini akan mengalami kesulitan ketika bekerja pada bagian aktivitas mencari dan menganalisis informasi. Menurut Anderson (Lestari, 2013: 2) bila berpikir kritis dikembangkan, seseorang akan cenderung untuk mencari kebenaran, berpikir divergen (terbuka dan toleran terhadap ide-ide baru), dapat menganalisis masalah dengan baik, berpikir secara sistematis, penuh rasa ingin tahu, dewasa dalam berpikir, dan dapat berpikir secara mandiri. Permasalahan yang dihadapi sekarang adalah pengembangan kemampuan berpikir kritis siswa di tingkat pendidikan dasar belum tertangani secara sistematis. Pendidikan di masa sekarang dianggap sangat mempersempit wawasan siswa, karena tidak membantu para siswanya untuk berpikir secara kritis.

Pendidikan matematika memiliki posisi yang strategis dalam mempersiapkan sumber daya manusia yang berkualitas. Melalui kemampuan matematika diharapkan dapat terbentuk generasi muda Indonesia yang memiliki sifat-sifat mampu berpikir logis, mampu berpikir rasional, cermat, jujur, efisien dan efektif. Hal-hal tersebut akan tercapai jika para siswa sendiri mau mengembangkan pengetahuannya dengan cepat, yaitu kemampuan berpikir menurut suatu alur kerangka berpikir tertentu, secara garis besar. Cara berpikir seperti ini disebut penalaran. Maka dari itu, keterampilan lain yang juga penting untuk dimiliki oleh siswa sekolah dasar adalah kemampuan penalaran. Seperti yang dijelaskan oleh Putri (2011: 1), bahwa “... kemampuan penalaran matematis sangat penting dimiliki siswa untuk meningkatkan pemahaman siswa terhadap kegunaan matematika itu sendiri”. Sejalan dengan hal tersebut, Kariadinata (2012:12) menjelaskan "pentingnya daya nalar bagi siswa tertuang pula dalam Permendiknas 2006 yang menyebutkan bahwa siswa belajar matematika agar memiliki kemampuan menggunakan penalaran pada pola dan sifat". Hal yang sama juga dikemukakan oleh Ekayanti (2013: 2) bahwa salah satu kompetensi dasar di dalam mata pelajaran matematika untuk tingkat sekolah dasar adalah agar siswa memiliki kemampuan menggunakan penalaran pada pola dan sifat, melakukan manipulasi matematika dalam membuat generalisasi, menyusun bukti, atau menjelaskan gagasan dan pernyataan matematika.

Dari uraian di atas, maka dalam menghadapi era globalisasi dengan segala tantangan dan problematikanya sangat penting bagi siswa untuk memiliki kemampuan berpikir kritis dan penalaran matematis. Namun pada kenyataannya beberapa hasil studi menunjukkan kemampuan berpikir kritis dan penalaran matematis siswa masih belum memuaskan.

Studi yang dilaksanakan oleh Trends in International Mathematics and Science Study (TIMSS), sebuah lembaga internasional yang mengukur hasil pendidikan di dunia, pada tahun 2011 melaporkan peringkat Indonesia di bidang matematika hanya berada di posisi 39 dari 
jumlah peserta seluruhnya 43 negara. Dalam studi tersebut, Indonesia hanya memperoleh skor 386 jauh di bawah ratarata skor internasional, yaitu 500. Dari studi tersebut juga terungkap bahwa siswa Indonesia masih lemah dalam menyelesaikan soal-soal tidak rutin yang berkaitan dengan pembuktian,pemecahan masalah yang memerlukan penalaran matematika, menemukan generalisasi atau konjektur, dan menemukan hubungan antara data-data atau fakta yang diberikan. Berdasarkan fakta di atas,dapat dikatakan bahwa kemampuan pemecahan masalah, kemampuan berpikir kritis, kreatif, dan reflektif siswa pada umumnya masih rendah.

\section{Dalam Program for International Students Assessment (PISA) yang diselenggarakan pada tahun 2009, sebagaimana dikutip dari Badan Penelitian dan Pengembangan (LITBANG)} Kementerian Pendidikan dan Kebudayaan (http://litbang.kemdikbud.go.id/index.php/s urvei-internasional-pisa), diketahui negara Indonesia hanya menduduki posisi 61 dari jumlah peserta sebanyak 65 negara. Kemampuan dalam bidang matematika Indonesia menunjukkan skor yang sangat rendah, yaitu 371 masih berada di bawah rata-rata Organization for Economic Cooperation and Development(OECD). Padahal soal-soal matematika dalam PISA mengukur kemampuan komunikasi, menalar, representasi, pemecahan masalah, berargumentasi, berkomunikasi dan berpikir tingkat tinggi.

Hasil Penelitian dari Windayana pada tahun 2007 memperlihatkan bahwa kemampuan berpikir kritis siswa sekolah dasar masih rendah. Hal ini ditunjukkan dengan rata-rata skor tes awal siswa yang hanya memperoleh 5,80. Rendahnya kemampuan berpikir kritis siswa juga terungkap dari penelitian yang dilakukan oleh Arvyaty dan Saputra pada tahun 2012. Penelitian yang dilakukan pada siswa SMP ini memperlihatkan hasil rata-rata skor tes kemampuan berpikir kritis hanya sebesar 58,18 dengan sekitar $85,72 \%$ siswa masuk dalam kategori di bawah cukup.

Dari temuan-temuan di atas menunjukkan bahwa kemampuan berpikir kritis dan penalaran matematis siswa memang tidak dibiasakan untuk dikembangkan sejak sekolah dasar. Sehingga tampak dengan jelasketika siswa beranjak ke tingkat menengah kemampuan kemampuan berpikir kritis dan penalaran matematis menjadi masalah terhadap siswa itu sendiri. Hal ini akan menjadi sebuah kekhawatiran yang sangat besar jika kemampuan tersebut tidak dikembangkan sejak sekolah dasar. Dengan demikian pengembangan kemampuan berpikir kritis dan penalaran siswa sekolah dasar perlu segera diperhatikan, karena akan berdampak pada jenjang pendidikan berikutnya.

Berdasarkan fakta-fakta tersebut di atas, maka guru sebagai ujung tombak pendidikan mempunyai peran yang sangat penting dalam mendorong terciptanya proses belajar secara optimal sehingga siswa belajar secara aktif dan memiliki kemampuan berpikir kritis serta penalaran matematis. Namun demikian, kenyataan di lapangan guru masih mengalami kesulitan bagaimana menyelenggarakan pembelajaran yang efektif. Seperti dikemukakan Zamroni (Hadi, 2003: 1), orientasi pendidikan di Indonesia pada umumnya mempunyai ciri-ciri sebagai berikut: (1) cenderung memperlakukan siswa berstatus sebagai obyek; (2) guru berfungsi sebagai pemegang otoritas tertinggi keilmuan dan indoktrinator; (3) materi bersifat subjectoriented; dan (4) manajemen bersifat sentralistis.

Masalah yang timbul dari kurangnya aktivitas atau peran aktif siswa dalam pembelajaran dapat diatasi dengan suatu model maupun pendekatan pembelajaran 
yang mengubah aktivitas belajar siswa yang pasif menjadi aktif. Dengan kata lain, siswa aktif dalam mengkonstruksikan konsepkonsep yang didukung oleh keseimbangan dalam pengetahuan, keterampilan dan sesuai dengan karakteristik siswa. Aktivitas belajar seperti ini dapat menghindarkan siswa dari rasa bosan, sehingga tercipta suasana belajar yang nyaman dan menyenangkan. Suasana pembelajaran yang nyaman dan menyenangkan hendaknya diusahakan pendidik dengan memperhatikan struktur dan fungsi otak, karena otak merupakan bagian terpenting dalam kegiatan belajar dan pembelajaran. Rakhmat (2005:13) menyatakan bahwa "belajar itu harus berbasis otak. Dengan kata lain revolusi belajar dimulai dari otak. Otak adalah organ paling vital manusia yang selama ini kurang dipedulikan oleh guru dalam pembelajaran". Desmita menambahkan (2012:94) bahwa "otak anak mempunyai kemampuan besar untuk menyusun ribuan sambungan antarneuron. Namun, kemampuan itu berhenti pada usia 10-11 tahun jika tidak dikembangkan dan digunakan". Oleh sebab itu, untuk terus meningkatkan kemampuan-kemampuan kognitif anak, proses pematangan otak harus dilaksanakan secara terus-menerus serta diiringi dengan peluang-peluang untuk mengenal dan mengalami dunia yang makin luas.

Berdasarkan pemaparan di atas, maka diperlukan suatu model pembelajaran yang mengoptimalkan kerja otak serta diperkirakan dapat meningkatkan kemampuan berpikir kritis dan dan penalaran matematis siswa. Salah satu alternatif model pembelajaran yang dapat meningkatkan kemampuan berpikir kritis dan penalaran matematis siswa serta menciptakan kondisi belajar yang menyenangkan dan aktif melibatkan siswa adalah model Brain-Based Learning (BBL).Menurut Akyurek (2013: 105) "BBL adalah pendekatan pembelajaran yang didasarkan pada struktur dan fungsi otak manusia. Berbeda dari metode kurikulum saat ini, pembelajaran berbasis otak menekankan pembelajaran bermakna bukan menghapal". Menurut Gulpinar (2005:302), yang membedakan BBL dengan model pembelajaran yang lain adalah BBL memiliki ciri khas pembelajaran yang rileks, pembelajaran yang konstruktivistik, pembelajaran yang menekankan aspek kerjasama antarsiswa, adanya cukup waktu bagi siswa untuk merefleksikan materi yang telah diterimanya, pembelajaran yang bermakna dan kontekstual. Hal yang sama juga dikemukakan oleh Bilal (2013: 2) bahwa pembelajaran $\mathrm{BBL}$ sangat menekankan pada bagaimana siswa dapat belajar lebih bermakna, karena hal ini dapat memperkaya pengalaman siswa. BBL menyediakan pembelajaran yang nyaman bagi siswa serta kesempatan untuk belajar secara lebih bermakna.

Caine dan Caine (dalam Hasliza,
2012:5) juga mengatakan bahwa mengoptimalkan penggunaan otak berarti menggunakan kapasitas otak yang tak terbatas untuk membuat koneksi dan memahami kondisi seperti apa yang akan memaksimalkan proses ini. Mereka mengidentifikasi tiga elemen interaktif dan saling mendukung yang harus ada agar pembelajaran yang kompleks terjadi. Ketiga elemen tersebut adalah Relaxed alertness, Orchestrated immerson dan Active proessing. Selanjutnya Safa'at (Abdurahman, 2013:2) mendefinisikan ketiga elemen tersebut sebagai berikut:

1. Menciptakan lingkungan belajar yang menantang kemampuan berpikir siswa. Dalam setiap kegiatan pembelajaran, sering-seringlah guru memberikan soalsoal materi pelajaran yang memfasilitasi kemampuan berpikir siswa dari mulai tahap pengetahuan (knowledge) sampai tahap evaluasi menurut tahapan berpikir berdasarkan Taxonomy Bloom. Soalsoal pelajaran dikemas seatraktif dan 
semenarik mungkin, misal melalui tekateki, simulasi games, dan sebagainya, agar siswa dapat terbiasa untuk mengembangkan kemampuan berpikirya dalam konteks pemberdayaan potensi otak siswa.

2. Menciptakan lingkungan pembelajaran yang menyenangkan. Hindarilah situasi pembelajaran yang membuat siswa merasa tidak nyaman dan tidak senang terlibat di dalamnya. Lakukan pembelajaran di luar kelas pada saatsaat tertentu, iringi kegiatan pembelajaran dengan musik yang didesain secara tepat sesuai kebutuhan di kelas, lakukan kegiatan pembelajaran dengan diskusi kelompok yang diselingi dengan permainan-permainan menarik, dan upaya-upaya lainnya yang mengeliminasi rasa tidak nyaman pada diri siswa.

Menciptakan situasi pembelajaran yang aktif dan bermakna bagi siswa (active learning). Siswa sebagai pembelajar dirangsang melalui kegiatan pembelajaran untuk dapat membangun pengetahuan mereka melalui proses belajar aktif yang mereka lakukan sendiri. Bangun situasi pembelajaran yang memungkinkan seluruh anggota badan siswa beraktivitas secara optimal, misal mata siswa digunakan untuk membaca dan mengamati, tangan siswa bergerak untuk menulis, kaki siswa bergerak untuk mengikuti permainan dalam pembelajaran, mulut siswa aktif bertanya dan berdiskusi, dan aktivitas produktif anggota badan lainnya. Merujuk pada konsep konstruktivisme pendidikan, keberhasilan belajar siswa ditentukan oleh seberapa mampu mereka membangun pengetahuan dan pemahaman tentang suatu materi pelajaran berdasarkan pengalaman belajar yang mereka alami sendiri.

\section{Metode Penelitian}

Penelitian ini merupakan studi kuasi eksperimen dengan desain penelitian berbentuk desain kelompok kontrol non ekuivalen. Peneliti memilih kuasi eksperimen karena pemilihan sampel tidak secara random tetapi menerima keadaan sampel seadanya. Hal ini dikarenakan eksperimen yang menjadikan manusia sebagai objek, seringkali dijumpai kondisi yang kurang memungkinkan peneliti melaksanakan penugasan random yang disebabkan oleh aturan administratif dan disebabkan tidak alaminya situasi kelompok subjek apabila penugasan random dilakukan.

Peneliti memilih desain kelompok kontrol non ekuivalen karena desain ini merupakan bagian dari bentuk kuasi eksperimen dengan jumlah kelas yang digunakan sebanyak dua kelas. Satu kelas dijadikan sebagai kelompok eksperimen dan satu kelas lainnya dijadikan sebagai kelompok kontrol. Terhadap kedua kelompok ini, sebelum pelaksanaan pemberian perlakuan, dilakukan pengukuran perlakuan awal atau pretes $(\mathrm{O})$. Selanjutnya terhadap kelompok eksperimen diberi perlakuan model Brain Based Learning (BBL) (X), sedangkan untuk kelompok kontrol tidak diberi perlakuan. Setelah itu, terhadap kedua kelompok diberi perlakuan pasca pemberian perlakuan atau postes $(\mathrm{O})$.

Populasi dalam penelitian ini adalah seluruh siswa kelas V SD di Kabupaten Majalengka pada tahun ajaran 2013/2014. Dari populasi tersebut selanjutnya peneliti mengambil sampel. Peneliti memilih kelas $\mathrm{V}$ sebagai subjek penelitian di SD Negeri Cijati, yaitu kelas V-A sebagai kelas eksperimen (Kelas yang memperoleh pembelajaran Model BBL) dan kelas V-B sebagai kelas kontrol (kelas yang memperoleh pembelajaran konvensional).

Instrumen untuk mengumpulkan data dalam penelitian ini berupa soal tes matematika, yaitu tes untuk mengukur kemampuan berpikir kritis dan penalaran 
matematis siswa. Adapun soal tes ini berbentuk soal uraian. Pemilihan bentuk tes uraian ini bertujuan melihat proses pengerjaan yang dilakukan siswa agar dapat diketahui sejauh mana siswa mampu berpikir kritis dan bernalar matematis.

Data kuantitatif dalam penelitian ini diperoleh melalui pretes maupun postes kemampuan berpikir kritis dan penalaran matematis. Pretes dan postes diberikan kepada dua kelompok siswa, yaitu yang terdiri dari 33 siswa yang mendapat pembelajaran dengan BBL (kelas eksperimen), dan 34 siswa yang mendapat pembelajaran secara konvensional (kelas kontrol). Adapun untuk mengetahui peningkatan kemampuan berpikir kritis dan penalaran matematis siswa setelah mendapatkan perlakuan, pada kelas eksperimen pembelajaran melalui BBL dan pada kelas kontrol pembelajaran konvensional, dilakukan analisis terhadap data data $N$-Gain. Seluruh perhitungan statistika dalam analisis ini menggunakan bantuan software SPSS 20 dan Microsoft Office Excel 2013, dengan tingkat signifikansi 5\%. Apabila data berdistribusi normal dan homogen, maka uji hipotesis penelitian akan menggunakan uji $t$ independent sample test, adapun apabila data berdistribusi normal dan tidak homogen, maka uji hipotesis penelitian dilakukan dengan menggunakan uji t' independen sample test, adapun apabila data tidak berdistribusi normal, maka uji hipotesis penelitian dilakukan dengan menggunakan uji non parametrik MannWhitney $U$.

\section{Hasil Penelitian dan Pembahasan}

Berdasarkan hasil penelitian diperoleh rata-rata skor $\quad N$-gain(peningkatan) kemampuan berpikir kritis siswa kelas eksperimen sebesar 0,528, sedangkan ratarata skor $N$-gain kemampuan berpikir kritis siswa kelas kontrol sebesar 0,407. Secara deskriptif, dapat diketahui bahwa rata-rata $N$-gain kemampuan berpikir kritis siswa kelas BBL dan kelas konvensional berbeda, dimana nilai rata-rata kelas BBL lebih tinggi daripada nilai rata-rata pada kelas konvensional.

Setelah dilakukan analisis deskriptif data, dilakukan uji prasyarat yaitu uji normalitas dan uji homogenitas. Untuk melakukan uji normalitas dari dua kelas tes kemampuan berpikir kritis (eksperimen dan kontrol) peneliti menggunakan statistik Shapiro-Wilks. Dari perhitungan menggunakan SPSS 20 terungkap bahwa nilai signifikansi berada di atas 0,05 untuk semua unit analisis. Hal ini menunjukkan bahwa sebaran data pada dua kelompok berdistribusi normal. Sedangkan uji homogenitas dari kedua kelas menggunakan Levene's test. Berdasarkan perhitungan SPSS 20, diperoleh nilai signifikansi Levene's test untuk data $N$-gain kemampuan berpikir kritis siswa adalah 0,69 , lebih besar dari nilai $\propto=0,05$. Dengan demikian dapat disimpulkan bahwa pada tingkat kepercayaan $95 \%$, varians data $N$-gain kemampuan berpikir kritis siswa matematis pada kedua kelas adalah homogen.

Hasil analisis uji normalitas dan uji homogenitas menunjukkan bahwa data $N$ gain kemampuan berpikir kritis siswa pada kedua kelas berdistribusi normal dan memiliki varians homogen. Dengan demikian, asumsi statistik untuk melakukan uji perbedaan dua rata-rata secara parametrik telah terpenuhi. Adapun dalam melakukan uji perbedaan dua rata-rata, dikarenakan data kedua kelas saling independen, maka untuk melihat bagaimana peningkatan kemampuan berpikir kritis siswa pada kedua kelas dilakukan menggunakan uji t independent sample test. Dengan perhitangan menggunakan SPSS 20 diperoleh nilai signifikansi 1-tailed uji t independent sample test data $N$-gain kemampuan berpikir kritis siswa adalah sebesar 0,0005 dan lebih kecil dari nilai $\propto=0,05$.Jadi, secara signifikan rata-rata 
$N$-gain kemampuan berpikir kritis siswa yang mendapatkan pembelajaran BBLlebih tinggi daripada siswa yang mendapatkan pembelajaran konvensional. Hal ini berarti pada tingkat kepercayaan $95 \%$, peningkatan kemampuan berpikir kritis siswa yang mendapatkan pembelajaran BBL lebih baik daripada siswa yang mendapatkan pembelajaran konvensional.

Adapun untuk analisis deskriptif kemampuan penalaran matematis diperoleh rata-rata skor $N$-gain kemampuan penalaran matematis siswa kelas eksperimen sebesar 0,556. Adapun rata-rata skor N-gain kemampuan penalaran matematis siswa kelas kontrol sebesar 0,407. Sehingga secara deskriptif, dapat disimpulkan bahwa rata-rata $N$-gain kemampuan penalaran matematis pada siswa kelas eksperimen dan kelas kontrol berbeda, dimana nilai rata-rata peningkatan kelas eksperimen, yaitu kelas yang memperoleh pembelajaran $\mathrm{BBL}$, lebih tinggi daripada nilai rata-rata peningkatan kelas kontrol, yaitu kelas yang memperoleh pembelajaran konvensional.

Sementara dalam uji normalitas, diperoleh bahwa nilai signifikansi berada di atas 0,05 untuk semua unit analisis. Hal ini menunjukkan bahwa sebaran data pada dua kelompok berdistribusi normal. Sedangkan uji homogenitas dari kedua kelas menggunakan Levene's test. Berdasarkan perhitungan SPSS 20, diperoleh nilai signifikansi Levene's test untuk data $N$-gain kemampuan berpikir kritis siswa adalah 0,01, lebih kecil dari nilai® $=0,05$. Dengan demikian dapat disimpulkan bahwa pada tingkat kepercayaan $95 \%$, varians data $N$-gain kemampuan penalaran matematis siswa pada kedua kelas adalah tidak homogen.

Hasil analisis uji normalitas dan uji homogenitas menunjukkan bahwa data $N$ gain kemampuan penalaran matematis siswa pada kedua kelas berdistribusi normal dan memiliki varians yang tidak homogen.
Dengan demikian, untuk melihat bagaimana peningkatan kemampuan penalaran matematis siswa pada kedua kelas dilakukan menggunakan uji t' independent sample test. Berdasarkan perhitungan SPSS 20, diperoleh nilai signifikansi 1-tailed uji $\mathrm{t}$ ' independent sample test data $N$-gain kemampuan penalaran matematis siswa adalah sebesar 0,006 dan lebih kecil dari nilai $\propto=0,05$ sehingga secara signifikan rata-rata $N$-gain kemampuan penalaran matematis siswa yang mendapatkan pembelajaran BBL lebih tinggi daripada siswa yang mendapatkan pembelajaran konvensional. Hal ini berarti pada tingkat kepercayaan 95\%, peningkatan kemampuan penalaran matematis siswa yang mendapatkan pembelajaran BBL lebih baik daripada siswa yang mendapatkan pembelajaran konvensional.

Dari paparan di atas, maka dapat disimpulkan bahwa pengaruh model BBL terhadap peningkatan kemampuan berpikir kritis matematis siswa lebih tinggi dibanding dengan pembelajaran konvensional. Hal ini dikarenakan banyak sekali aktivitas-aktivitas belajar pada model BBL yang dapat menunjang terhadap pengembangan kemampuan berpikir kritis siswa. Beberapa aktivitas belajar siswa yang sangat menunjang dalam pengembangan kemampuan berpikir kritis diantaranya adalah para siswa dibimbing guru berdiskusi secara kelompok untuk memahami materi yang diberikan. Cara belajar seperti ini dapat menuntut siswa untuk menjadi lebih aktif dalam belajar. Selain itu, dalam pembelajaran BBL siswa diberikan proyek, dalam bentuk LKS, tekateki maupun permainan, yang fungsinya untuk memfasilitasi siswa membangun pengetahuan dan pemahamannya berdasarkan pengalaman belajar mereka sendiri. Aktivitas-aktivitas belajar siswa dengan menggunakan BBL sangat bertolak belakang dengan menggunakan model pembelajaran konvensional. Aktivitas belajar siswa dengan menggunakan 
pembelajaran konvensional, pembelajarannya cenderung berpusat kepada guru dan memperlakukan siswa berstatus sebagai objek. Siswa menjadi pasif karena proses pembelajaran dilakukan hanya dengan guru mentransfer gagasannya kepada siswa. Hal ini dapat mengekang kreativitas belajar siswa yang pada akhirnya dapat menyebabkan sulitnya siswa untuk mengembangkan kemampuan berpikir kritisnya. Adapun aktivitas belajar siswa dengan menggunakan model BBL, seperti dipaparkan di atas, diyakini mampu meningkatkan kemampuan berpikir kritis matematis siswa.

Hal ini sejalan dengan pemaparan sebelumnya bahwa berpikir kritis merupakan proses aktif, sehingga tidak dapat diajarkan hanya melalui metode ceramah. Proses berpikir kritis dalam pembelajaran matematika dapat dikembangkan melalui proses pembelajaran yang kontruktivisme, adapun BBL adalah model pembelajaran yang memberikan kesempatan kepada siswa untuk membangun pengetahuannya sendiri secara aktif. Selain dari itu, Sapa'at (2013) juga mengemukakan bahwa salah satu strategi dalam BBL, yaitu model ini menciptakan lingkungan belajar yang menantang kemampuan berpikir siswa yang disesuaikan dengan cara otak bekerja secara alamiah untuk belajar. Ini yang mendasari bahwa pembelajaran BBL dapat meningkatkan kemampuan berpikir kritis matematis siswa.

Berdasarkan penelitian mengenai
peningkatan kemampuan penalaran
matematis, model BBL pengaruh yang lebih
tinggi dibanding dengan pembelajaran
konvensional. Hal ini dikarenakan banyak
sekali aktivitas-aktivitas belajar pada model
BBL yang dapat menunjang terhadap
pengembangan kemampuan penalaran
matematis siswa dibanding pembelajaran
konvensional. Beberapa aktivitas belajar
siswa yang dapat mengembangkan

kemampuan penalaran matematis siswa di antaranya adalah para siswa diberikan sebuah proyek (LKS). Dalam proyek tersebut terdapat beberapa pasangan bangun datar yang sebangun dan yang tidak sebangun. Selanjutnya, siswa secara berkelompok diminta mencari ukuran dari masing-masing bangun datar dan menuliskan hasil pengukurannya pada lembar LKS yang telah disediakan. Dari hasil pengukuran tersebut, siswa diminta untuk membuat perbandingan antara panjang sisi-sisi yang bersesuaian dari setiap bangun datar dengan pasangannya. Dari hasil perbandingan tersebut, siswa akhirnya menemukan ada beberapa pasangan bangun datar yang memiliki perbandingan yang sama. Selanjutnya, guru menyimpulkan dan menjelaskan bahwa jika dua bangun datar yang panjang sisi-sisi bersesuaiannya sama, maka kedua bangun datar tersebut sebangun. Dalam aktivitasaktivitas tersebut peran guru hanya membimbing dan mengarahkan. Dengan kata lain, dalam pembelajaran tersebut siswa yang lebih aktif. Guru memberikan kesempatan dan keleluasaan kepada siswa untuk menemukan pengetahuannya sendiri dalam menemukan konsep dua bangun datar yang sebangun. Aktivitas belajar seperti ini dapat mengembangkan kemampuan penalaran siswa, karena di sini siswa dituntut untuk meneliti dan menghubungkan dua fakta sampai ditemukan adanya kesamaan pola atau sifat dari kedua fakta tersebut. Aktivitasaktivitas tersebut adalah aktivitas bernalar yang tentunya dapat meningkatkan kemampuan penalaran matematis siswa.

Hal ini sejalan sejalan dengan pemaparan sebelumnya bahwa model pembelajaran yang dapat meningkatkan kemampuan penalaran matematis seorang siswa adalah proses pembelajaran yang berbasis konstruktivisme dan Contextual Teaching and Learning (CTL). Adapun BBL adalah model pembelajaran yang menekankan agar siswa diberikan 
keleluasaan untuk menemukan dan menerapkan gagasan-gagasan secara aktif dengan memperhatikan potensi otak dan keseimbangan kerja otak dalam belajar.

\section{Kesimpulan}

Berdasarkan hasil penelitian dan pembahasan pada bagian terdahulu mengenai kemampuan berpikir kritis dan penalaran matematis siswa melalui model Brain-Based Learning (BBL), diperoleh kesimpulan berikut ini.

1. Siswa yang memperoleh pembelajaran melalui model BBL mengalami peningkatan kemampuan berpikir kritis yang lebih baik dibanding siswa yang belajar melalui pembelajaran biasa (konvensional).

2. Siswa yang memperoleh pembelajaran melalui model BBL mengalami peningkatan kemampuan penalaran matematis yang lebih baik dibanding siswa yang belajar melalui pembelajaran biasa (konvensional).

\section{DAFTAR PUSTAKA}

Abdurrahman, G. \& Sintawati, M. (2013). Strategi Brain-Based Learning Dalam Pembelajaran Matematika untuk Mengembangkan Kemampuan Berpikir Kritis dan Kreatif Siswa. Dalam Seminar Nasional Matematika dan Aplikasinya. Pendidikan Matematika, Program Pascasarjana, Universitas Negeri Yogyakarta.

Akyurek, E. (2013). Effects of Brain-Based Learning Approach on Students' Motivation and Attitudes Levels in Science Class. Mevlana International Journal of Educations. (3). hlm. 104119.

ilal, D. (2010). The Effects of Brain-Based Learning on the Academic Achievement of Students with Different Learning Styles. Journal of Educational Sciences : Theory \& Practice. (10). hlm. 2077-2103.
Desmita. (2012). Psikologi Perkembangan Peserta Didik. Bandung. PT. Remaja Rosdakarya.

Ekayanti, S., B \& Rudiana, U. (2013). Pemanfaatan CD Interaktif sebagai Upaya meningkatkan Penalaran Siswa pada Pembelajaran Matematika. Jurnal Pendidikan dan Pembelajaran. (2). hlm. 1-14.

Gulpinar, M. (2005). The Principles of Brain-Based Learning and Constructivist Models in Education. Journal of Educational Science : Theory and Practice. (5). hlm. 299306.

Hadi. S. (2003). Pendidikan Realistik: Menjadikan Pelajaran Matematika Lebih Bermakna bagi Siswa. Dalam Makalah yang Disampaikan pada Seminar Nasional Pendidikan Matematika 'Perubahan Paradigma dari Paradigma Mengajar ke Paradigma Belajar'. Yogyakarta. Universitas Sanata Dharma

Hasliza, A. (2012). New Way to Learn, New Way to Succes : Transforming a Brain-Based Learning Library Via Active Learning Instruction. Proceeding of the IATUL Conferences. Universitas Sains Malaysia.

Kariadinata, R. (2012). Menumbuhkan Daya Nalar (Power of Reason) Siswa Melalui Pembelajaran Analogi Matematika. Jurnal Infinity. (1). hlm. 10-18.

Lestari, K.E., (2013). Implementasi BrainBased Learning untuk Meningkatkan Kemampuan Koneksi dan Kemampuan Berpikir Kritis Matematis Siswa Sekolah Menengah Pertama. Tesis Sekolah Pascasarjana, UPI Bandung.

Putri, H. E. (2011). Kemampuan Penalaran Matematik dalam Pembelajaran 
Matematika di SD. Jurnal

Pengajaran MIPA. (6). hlm 18-21.

Rahkmat, J. (2005). Belajar Cerdas:

Belajar Berbasiskan Otak. Bandung. Mizan.

indayana. (2007). Pembelajaran Matematika Realistik dalam meningkatkan berpikir logis, kreatif, dan Kritis serta Komunikasi Matematis Siswa Sekolah Dasar. Jurnal Pendidikan Dasar (8). hlm 35-40. 